\title{
Knowledge sharing and affective commitment: the mediating role of psychological ownership
}

\author{
Li, Jian; Yuan, Ling; Ning, Lutao; Li-Ying, Jason
}

Published in:

Journal of Knowledge Management

Link to article, DOI:

10.1108/JKM-01-2015-0043

Publication date:

2015

Document Version

Peer reviewed version

Link back to DTU Orbit

Citation (APA):

Li, J., Yuan, L., Ning, L., \& Li-Ying, J. (2015). Knowledge sharing and affective commitment: the mediating role of psychological ownership. Journal of Knowledge Management, 19(6), 1146-1166. https://doi.org/10.1108/JKM01-2015-0043

\section{General rights}

Copyright and moral rights for the publications made accessible in the public portal are retained by the authors and/or other copyright owners and it is a condition of accessing publications that users recognise and abide by the legal requirements associated with these rights.

- Users may download and print one copy of any publication from the public portal for the purpose of private study or research.

- You may not further distribute the material or use it for any profit-making activity or commercial gain

- You may freely distribute the URL identifying the publication in the public portal

If you believe that this document breaches copyright please contact us providing details, and we will remove access to the work immediately and investigate your claim 


\section{Emerald Insight}

\section{Journal of Knowledge Management}

Knowledge sharing and affective commitment: the mediating role of psychological ownership

Jian Li Ling Yuan Lutao Ning Jason Li-Ying

\section{Article information:}

To cite this document:

Jian Li Ling Yuan Lutao Ning Jason Li-Ying , (2015),"Knowledge sharing and affective commitment: the mediating role of psychological ownership", Journal of Knowledge Management, Vol. 19 Iss 6 pp. -

Permanent link to this document:

http://dx.doi.org/10.1108/JKM-01-2015-0043

Downloaded on: 07 September 2015, At: 18:00 (PT)

References: this document contains references to 0 other documents.

To copy this document: permissions@emeraldinsight.com

The fulltext of this document has been downloaded 17 times since 2015*

\section{Users who downloaded this article also downloaded:}

John Israilidis, Evangelia Siachou, Louise Cooke, Russell Lock, (2015),"Individual variables with an impact on knowledge sharing: The critical role of employees' ignorance.", Journal of Knowledge Management, Vol. 19 Iss 6 pp. -

Vincenzo Cavaliere, Sara Lombardi, Luca Giustiniano, (2015),"Knowledge sharing in knowledge-intensive manufacturing firms. An empirical study of its enablers", Journal of Knowledge Management, Vol. 19 Iss 6 pp. -

Stanley C. Gardiner, (1993),"MEASURES OF PRODUCT ATTRACTIVENESS AND THE THEORY OF

CONSTRAINTS", International Journal of Retail \&amp; Distribution Management, Vol. 21 Iss 7 pp. - http://

dx.doi.org/10.1108/09590559310046040

Access to this document was granted through an Emerald subscription provided by emerald-srm: 122143 []

\section{For Authors}

If you would like to write for this, or any other Emerald publication, then please use our Emerald for Authors service information about how to choose which publication to write for and submission guidelines are available for all. Please visit www. emeraldinsight. com/authors for more information.

\section{About Emerald www.emeraldinsight.com}

Emerald is a global publisher linking research and practice to the benefit of society. The company manages a portfolio of more than 290 journals and over 2,350 books and book series volumes, as well as providing an extensive range of online products and additional customer resources and services.

Emerald is both COUNTER 4 and TRANSFER compliant. The organization is a partner of the Committee on Publication Ethics (COPE) and also works with Portico and the LOCKSS initiative for digital archive preservation. 


\title{
Knowledge sharing and affective commitment: the mediating role of psychological ownership
}

\begin{abstract}
Purpose

The purpose of this paper was to investigate the meditating role of psychological ownership which includes both organisation-based (OPO) and knowledge-based (KPO) psychological ownership on the relationship between affective commitment and knowledge sharing.
\end{abstract}

\section{Design/methodology/approach}

This paper was an empirical study based on structural equation modelling (SEM) with a sample of 293 employees from 31 high-technology firms in China.

\section{Findings}

The result indicated that (1) affective commitment had a significant positive effect on OPO but no effect on KPO; (2) OPO was positively related to both common and key knowledge sharing while KPO exerted a negative impact on both; (3) common knowledge sharing was positively related to key knowledge sharing; (4) the relationship between affective commitment and key knowledge sharing was multi-mediated by OPO and common knowledge sharing.

\section{Originality/value}

OPO and KPO play an essential role in transferring the effect of employees' affective commitment to common knowledge sharing and key knowledge sharing, which unravels the blackbox of how effective commitment affects knowledge sharing.

Keywords: knowledge sharing; common knowledge; psychological ownership; affective commitment; structural equation modelling 


\section{Introduction}

Knowledge sharing has been well documented as a vital way for firms to develop skills and competences to stay competitive (Grant, 1996; Spender, 1996; Liu and Liu, 2011; Ramirez and $\mathrm{Li}, 2009)$. It is a prerequisite for innovation as ideas or concepts rely on effective knowledge sharing among employees to be converted and applied at the organisational level for the development of new products, services and processes (Nonaka and Takeuchi, 1996; Nonaka, Von Krogh and Voelpel, 2006). Nevertheless, knowledge sharing might potentially evoke conflicts of interest among individuals (Krogh, Roos, and Slocum, 1994; Nonaka, Von Krogh, and Voelpel, 2006; Davenport, David, and Beers, 1998; Liu and DeFrank, 2012). Firms therefore are always on the lookout for tools or systems that can overcome organisational and individual barriers, enabling employees to share knowledge effectively so as to improve innovation performance (Schwaer, Biemann, and Voelpel, 2012).

Previous literature has studied a number of important antecedents for knowledge sharing. For example, the types of organisational structure that improve the efficiency of knowledge sharing (e.g., a centralised and functional structure, and organisational hierarchy) (Nonaka and Takeuchi, 1996; Pierce, 2012), and the impact of organisational culture and climate (e.g., organisational culture oriented toward innovation or individual competition) (Argote and Ingram, 2000; Bock, Zmud, Kim, and Lee, 2005). Also, at the individual level, there is the motivation and perception of individuals toward knowledge sharing (e.g., rewards, organisational justice, personality and trust) (Gagné, 2009; Ibragimova, 2006; Lin, 2007; Matzler, Renzl, Mooradian, von Krogh, and Mueller, 2011; Liao, 2008; Schwaer et al., 2012).

Scholars have found that affective commitment is positively related to knowledge sharing (Camelo-Ordaz, Garcia-Cruz, Sousa-Ginel, and Valle-Cabrera, 2011; Hislop, 
2003; van den Hooff and De Ridder, 2004), once individuals developed a positive emotion toward an organisation, the intention to perform extra-role behaviours, such as knowledge sharing will grow because it demands positive intrinsic motivation (Becker and Kernan, 2003; Meyer, Stanley, Herscovitch, and Topolnytsky, 2002; Williams and Anderson, 1991). Despite the growing literature (Cabrera and Cabrera, 2005; Han, Chiang, and Chang, 2010; Liu and Liu, 2011; Liu and DeFrank, 2012; Matzler et al., 2011; Schwaer et al., 2012), relatively little research has focused on the path that links individual cognition, motivation, and behaviours of knowledge sharing. This creates difficulties in understanding the impact of knowledge sharing on organisational effectiveness as well as some mediating factors and antecedents.

This paper studies the meditation roles of organisation-based psychological ownership (OPO) and knowledge-based psychological ownership (KPO) on the relationship between affective commitment and knowledge sharing. The authors employ a conceptual model based on logic that links 'how I feel' (affective commitment), 'what I should do' (psychological ownership), and 'what I do' (knowledge sharing). 'Knowledge sharing', 'what I do', is based on an individual action but requires interactions with other individuals and needs to be placed in a group context. It is thus necessary to aggregate this micro-level concept in order to explain a meso-level phenomena for improving organisational effectiveness (Felin and Barney, 2013).

The nuanced effect of affective commitment on knowledge sharing can be much more complicated than previous research frameworks suggest. The positive effect of affective commitment may be 'transferred through' other mediators. The authors focus on the psychological ownership in this paper as a critical mediator in the relationship between affective commitment and knowledge sharing. This is mainly because employees' sense of ownership can result in an altruistic spirit (Pierce, Kostova, and 
Dirks, 2001), thus contributing to organisational effectiveness, such as knowledge sharing. Moreover, Avey et al. (2009) extended the classical concept of psychological ownership and suggested that it in fact contains both positive and preventive aspects. The authors therefore include psychological ownership from two perspectives in the framework, i.e., employees' ownership of their organisation and their own personal knowledge. The authors propose that individuals with a higher level of OPO are more likely to share their knowledge with others, whereas those who cherish their knowledge and focus on the control of knowledge (KPO) might be reluctant to share knowledge with others.

Nevertheless, knowledge sharing is not a simple construct (Sitlington, 2012; Yen, Tseng, and Wang, 2014). Van den Hooff and De Ridder (2004) distinguished between denoting knowledge (i.e., communication with others about his/her personal intellectual capital) and collecting knowledge (i.e., consulting co-workers to get them to share their intellectual capital), and indicated that affective commitment has positive effects on both. Other scholars have tried to understand knowledge from the perspective of its nature, and argued that knowledge sharing is more difficult and more valuable for organisations to establish core competence with tacit knowledge (Augier, Shariq, and Vendelø, 2001; Lin, 2007; Swift and Virick, 2013; Hu and Randel, 2014). Along with this strand of literature, the authors argue that individuals are reluctant to share 'key knowledge' that is related to their core interests whereas they are willing to share 'common knowledge' that is frequently used or not concerned with personal interests. The authors refer to the first type of knowledge sharing as key knowledge sharing, and the other as common knowledge sharing. Key knowledge includes some codified knowledge while common knowledge contains the tacit one. In other words, the distinction between key and common knowledge is more comprehensive and closer to the reality of knowledge 
sharing in daily life than other classifications of knowledge sharing. The authors further hypothesised a positive association between common knowledge sharing and key knowledge sharing.

This paper extends and contributes to the knowledge sharing literature in two main ways. Firstly, this study contributes to analysis of affective commitment by examining its influence through two types of psychological ownership on both key knowledge sharing and common knowledge sharing. Although affective commitment is important in facilitating knowledge sharing (Matzler et al., 2011), the authors argue that psychological ownership plays a significant role in this process. Individuals' knowledge sharing is an extra-role behaviour that is usually encouraged by strong intrinsic motivations (Lin, 2007). This study attempts to understand it via two practical aspects which overcome some drawbacks of existing distinctions of knowledge sharing. Examining how affective commitment and the two types of psychological ownership affect both common and key knowledge sharing is an important test of their validity as a positive mental resource and extends the understanding of psychological ownership and knowledge sharing. In this way, this paper also contributes to the micro-foundation of knowledge management (McAdam and McCreedy, 2000) by providing a viable way of understanding the dynamics among individual-level attributes.

Second, this research contributes empirically to the management of knowledge in human resources. Current organisational paradigms for encouraging knowledge sharing tend to focus on using modern IT facilities and technologies, or providing individuals with a comfortable workplace. Relatively little attention has been paid to connecting human resource management with organisational knowledge management (Han et al., 2010). This study suggests that a positive regulatory system and organisational culture are helpful to increase individuals' emotional attachment and responsibility in 
organisations (Cushen and Thompson, 2012). A high level of affective commitment and the sense of being an 'owner' of an organisation can encourage more knowledge sharing behaviours among individuals. Moreover, routine sharing of common knowledge would lead to a high possibility of key knowledge sharing (Nonaka et al., 2006). This research suggests that managers take account of the importance of psychological aspects of individuals when attempting to encourage knowledge sharing in organisations.

The remainder of the paper is as follows. In the next section, the authors develop several hypotheses in light of theoretical and empirical works on knowledge sharing and physiological and organisation ownership. Following this, the authors describe the data and methodology and then report research results. The last section concludes the paper.

\section{Theoretical Development}

\subsection{Affective commitment and psychological ownership}

Affective commitment has been regarded as organisational commitments and reflects an important aspect of employees' motivation of working in organisations (Allen and Meyer, 1990; Meyer and Allen, 1991). The authors focus on affective commitment in this research as it refers to individuals' identification and involvement with, and emotional attachment to, an organisation and its goals (Camelo-Ordaz et al., 2011; Meyer et al., 2002). Employees' emotional attachment is believed to be a main driver of their intention to remain in an organisation and cherish the opportunity of working there (Wright and Kehoe, 2008). From the perspective of social identification, affective commitment is an employee's strongest emotional sense that attaches to an organisation as well (Carmeli, 2005; Ellemers, Kortekaas, and Ouwerkerk, 1999).

Prior studies connected employees' affective commitment with their psychological ownership, and suggested a positive link between them (Han et al., 2010; O'driscoll, 
Pierce, and Coghlan, 2006; Sieger, Bernhard, and Frey, 2011; van den Hooff and De Ridder, 2004). Psychological ownership is defined as an individual's cognitive ownership of tangible or intangible targets (Pierce et al., 2001). Such cognition makes individuals regard substantial or non-substantial things as their personal belongings (Belk, 1988). More precisely, psychological ownership is 'the state in which individuals feel as though the target of ownership or a piece of that target is theirs', and reflects 'an individual's awareness, thoughts, and beliefs regarding the target of ownership' (Pierce, Kostova, and Dirks, 2003, p. 86).

The term 'target' in the psychological ownership literature is quite broad, including personal or group attachment, facilities in the work place, and personal output in an organisation (Avey et al., 2009; Pierce et al., 2001). Such targets of ownership are likely to be deeply rooted in an individual's self-identity which leads to a view of extension of oneself (Cram and Paton, 1993; Dittmar, 1992). The key feature of psychological ownership is controlling an object. Pierce et al. (2001) suggested that the higher the level of employees' controlling sense, the more likely they view objects (targets) as extensions of themselves. Indeed, ownership and self-identity are interrelated, both of which lead to employees' territorial behaviours. Specifically, employees tend to mark or defend their territory in a sense of identifying and protecting belongings as an extension of themselves (Brown, Lawrence, and Robinson, 2005). Van Dyne and Pierce (2004) pointed out that OPO is the extent to which an individual feels ownership of an organisation while organisational commitment is the degree to which an individual wants to continue his/her membership in an organisation.

The target of OPO varies according to the different levels of an organisation, for instance organisations, departments, teams, and groups (Pierce et al., 2001). The perception of belonging to an organisation is a type of personal sense of organisational 
membership (McMillan and Chavis, 1986). In this study the authors predict that a higher level of OPO will encourage individuals to perceive organisational development as a part of self-development, and become more favourable towards their work. Similar to other psychological resources, psychological ownership can be invested in and developed (Avey et al., 2009). The authors argue that affective commitment is an antecedent of $\mathrm{OPO}$ as personal feelings of various aspects of the organisation may occur in a straightforward way, although emotional attachment needs some time to accumulate. OPO may be a higher order psychological status toward the organisation, and once individuals accumulate a certain level of emotional attachment with the organisation they are more likely to treat the organisation as an important belonging of themselves from the psychological perspective. Indeed, the authors admit that OPO may in turn have a positive impact on reinforcing individuals' personal preference for an organisation. In this study the authors argue that affective commitment has a main direct effect on OPO.

Hypothesis 1: Affective commitment is positively related to OPO.

Besides OPO, the authors focus on KPO as well. Personal cognition of knowledge varies due to various personal traits, for instance gender, age, education level, etc. (Matzler et al., 2011; Matzler, Renzl, Müller, Herting, and Mooradian, 2008). Similar to OPO, employees' KPO is a sense of personal control for their knowledge, and the mental cognition that knowledge is a personal belonging. Avey et al. (2009) suggested two distinct forms of ownership. These included a more defensive, prevention-based ownership, and a more constructive, promotion-focused ownership, KPO is in line with the first form. The importance of knowledge has been highlighted in the knowledge based economy era. Due to the intimate relationship between knowledge and innovation, employees' ideas are the source of organisational innovation (Kimberly and Evanisko, 
1981). With such background, employees become more sensitive and careful in protecting their knowledge.

Moreover, Avey et al. (2009) argued that psychological territoriality prevents the flow of information across personal boundaries, while the distinction between personal and organisational boundaries might be ambiguous when employees offer emotional attachment to organisations. In other words, personal wisdom could contribute to an organisation's knowledge reservoir (Meso and Smith, 2000; Kim and Lee, 2006). Affective commitment is a helpful 'tool' to mitigate the ownership of personal knowledge. It is more likely that individuals with high emotional investment in an organisation treat their knowledge as a 'public' product and pay less attention to their personal control of such knowledge (Wright and Kehoe, 2008). As prior literature points out, affective commitment is conducive to positive psychological behaviours (Luthans, 2002), e.g., job satisfaction and organisational citizenship behaviours etc. The low level of control of personal knowledge, experience, and skill is helpful to stimulate individuals' positive psychological behaviours. Therefore, the authors posit the following hypothesis.

Hypothesis 2: Affective commitment is negatively related to KPO.

\subsection{Psychological ownership and knowledge sharing}

Knowledge sharing refers to activities that individuals engage in that involve sending or receiving knowledge from others (Cabrera and Cabrera, 2005; Schwaer et al., 2012), and both sender and receiver are equally entitled to the ownership of the knowledge during this process. Accumulating knowledge is vital for organisational innovation (Cohen and Levinthal, 1990), and knowledge sharing is believed to be useful in amplifying the knowledge stock of organisations (Cabrera and Cabrera, 2005; Haas and Hansen, 2007). 
However, knowledge sharing is a sensitive process and requires employees' engagement (Granovetter, 1973; Hansen, 1999; Nahapiet and Ghoshal, 1998; Reagans and McEvily, 2003; Szulanski, 2000). Adopting proper mechanisms (e.g., valuing employees' voices and designing promotion channels for employees) can encourage employees to match self-development with organisational objectives. The benefits produced by these mechanisms for both employers and employees are conducive to improving organisational efficiency that is reinforced by increasing key knowledge sharing within organisational boundaries (Bowen and Lawler, 1992).

OPO is a feeling of identifying organisational boundaries that make organisation members share knowledge or information to indicate organisational membership (McMillan and Chavis, 1986). In fact, when employees perceive the controlling object as extensions of themselves (Pierce et al., 2001), they have a reciprocal responsibility or obligation toward the object. Employees' altruistic spirit is more likely to be encouraged in such circumstances, which can stimulate more organisational citizenship behaviours (Masterson and Stamper, 2003). Prior studies found that job satisfaction, work performance, etc., could be predicted by OPO (Avey et al., 2009; Pierce et al., 2001, 2003). In other words, an individual's OPO encourages a series of positive psychological feelings and behaviours. Van Dyne and Pierce (2004) pointed out that employees with a feeling of psychological ownership of their organisation may display an altruistic spirit, which has been viewed as an important antecedent for extra-role behaviour (e.g., knowledge-sharing) (Podsakoff, MacKenzie, Paine, and Bachrach, 2000). Hence, the authors posit that individuals with a higher level of OPO will be more likely to share knowledge with others.

Hypothesis 3: OPO is positively related to both common and key knowledge sharing. According to Higgins' $(1997,1998)$ regulatory focus theory, promotion and 
prevention are two fundamental self-regulation systems. Based on the regulatory focus theory, employees' psychological ownership of an organisation refers to a promotionfocused approach that pursues goals that reflect their hopes and aspirations, whereas employees' KPO involves prevention goals that show their intention to avoid punishment and obey rules and obligations (Higgins, 1997, 1998; Kark and Van Dijk, 2007). Preventative focus is necessary when employees are aiming to guarantee stability, safety, and predictability (Avey et al., 2009). Compared with promotion focus, employees with prevention focus were more reluctant to exchange tangible and intangible assets with colleagues (Avey et al., 2009; Liberman, Idson, Camacho, and Higgins, 1999).

In accordance with previous arguments, employees' psychological ownership of knowledge is a manifestation of psychological territoriality that prevents outbound knowledge flow across personal boundaries. Sharing knowledge with others does not mean lost ownership of the knowledge, but the risk that conflicts of personal interests between sharers and receivers are increased (Krogh et al., 1994; Von Krogh, 1998). If employees expect infringement on their targets of ownership, they may act to protect their territory to demonstrate their ownership (Avey et al., 2009). As noted by Brown et al. (2005), individuals are more likely to conduct territorial behaviours when they hold stronger psychological ownership of an object. Moreover, employees' fear of losing their territory and social identity and associated self may prohibit collaboration, transparency, and information sharing (Avey et al., 2009). Therefore, employees who care about personal knowledge are more likely to protect the ownership of knowledge in a manner of avoiding sharing with others. The authors therefore propose the following hypothesis:

Hypothesis 4: KPO is negatively related to both common and key knowledge sharing.

The majority of empirical evidence supports a positive association between 
affective commitment and knowledge sharing (Camelo-Ordaz et al., 2011; Matzler et al., 2011). However, according to the preceding sections the authors strongly believe that affective commitment in fact transfers its positivity to knowledge sharing through other psychological variables.

An increasing number of studies adopt a distal-proximal approach to examine effects of personality and motivation on behaviour (e.g., Chen and Lim, 2012). Specifically, personality is frequently set as a distal cause of behaviours with a proximal factor like motivation. The authors argue that affective commitment is a distal variable that affects both common and key knowledge transfer. Specifically, individuals' affective commitment affecting their psychological ownership - (i) securing OPO and (ii) mitigating KPO. Their psychological ownership, in turn, activates sharing motivation that will either facilitate or impede common and key knowledge sharing. Therefore, the relationships between individuals' affective commitment and their knowledge sharing are mediated by their organisation and KPO. Thus, the authors posit that:

Hypothesis 5a: OPO mediates the relationship between affective commitment and both common and key knowledge sharing.

Hypothesis 5b: KPO mediates the relationship between affective commitment and both common and key knowledge sharing.

\subsection{Common and key knowledge sharing}

As discussed in previous sections, an individual's knowledge sharing is not a simplistic behaviour. Based on the varying codification of knowledge, knowledge sharing has been divided into several distinct types. For example, Zander and Kogut (1995) distinguished between four types of knowledge sharing based on the range of written to embodied knowledge, while Cummings (2004) proposed five types knowledge sharing from the 
perspective of specific content of shared knowledge. Indeed, knowledge cannot be easily shared (Krogh et al., 1994; Zander and Kogut, 1995; Szulanski, 2000) while the properties of knowledge are closely related to knowledge sharing, diffusion, retention, and accumulation (Argote, McEvily, and Reagans, 2003). The distinction between tacit and explicit knowledge is crucial, since it is helpful to understand the difficulty of knowledge transfer (Polanyi, 1966; Nelson and Winter, 1982; Ikujiro and Hirotaka, 1995; Baumard, 1999). However, this distinction may not be the best way to describe knowledge sharing since individuals seldom consider whether the knowledge is tacit or codified when trying to share knowledge with others. Instead, individuals are more likely to consider whether sharing knowledge will harm self-interests in the future (Krogh et al., 1994; Von Krogh, 1998). In other words, an important factor that impacts the decision to share knowledge is whether the knowledge has a close relationship with personal core interests. The authors define this type of knowledge as key knowledge and the others as common knowledge.

According to the interview with some staff in a machine manufacturing factory and a high technology firm, the majority of them suggest that they are more likely to share key knowledge with colleagues if they believe that the colleagues are worthy of sharing the knowledge. In other words, individuals are more likely to share key knowledge when they believe the receivers will not undermine senders' benefits. Indeed, the more frequently one shares with others, the more likely it is they benefit from knowledge sharing and then encourage key knowledge sharing. In line with this logic and preceding arguments, the authors predict that both the organisation and KPO are more likely to affect individuals' common knowledge sharing, and common knowledge sharing, in turn, affecting their key knowledge sharing. On the basis of these arguments, the authors posit that: 
Hypothesis 6a: Common knowledge sharing is positively related to key knowledge sharing.

Hypothesis 6b: Common knowledge sharing mediates the relationship between OPO and KPO with key knowledge sharing.

Hypothesis 6c: Common knowledge sharing and psychological ownership mediate the relationship between affective commitment and key knowledge sharing.

\section{Research methodology and variable construction}

\subsection{Sample and procedures}

The authors collected data for this study via mail surveys. Suggested by Brislin (1970), the authors translated English-language scales into Chinese and then independently back translated into English to ensure equivalence. To validate the scale translation, the authors invited two English major professors to carefully review the scales. The authors also discussed the scale translation with two professors in the organisational behaviour field. During this process, the authors further improved the questionnaire according to their helpful suggestions. Moreover, prior to administering the survey, the authors conducted a pre-test with a group of MBA students and $\mathrm{PhD}$ candidates $(\mathrm{n}=10)$ to obtain feedback regarding the clarity of language and presentation of items in the survey.

To test the relationships between the constructs, the authors conducted the survey in principal cities, e.g., Beijing, Shanghai, Guangzhou, etc, and in a central province of China (Hunan Province). The authors randomly selected 50 high technology firms based on the list of high technology manufacturers in local Science Park. A total of 500 copies (10 for each firm) of the questionnaires were sent out by mail. A cover letter with an explanation of the research and a standardised, self-report questionnaire were included. For some companies, the authors called the supervisors or the general managers to 
introduce the research objective and ask for assistance in administering the questionnaires. For each company, employees were randomly selected and asked to complete the questionnaire and return it to the research team directly so as to guarantee anonymity and the confidentiality of their answers. The survey was conducted in July and August of 2012, and the authors received 293 valid responses from 31 firms, yielding a final response rate of approximately 58.6 per cent. 59 per cent of respondents were male and nearly 74 per cent of were under 30 years old with an average tenure of about 3.5 years. Over half of the respondents ( 57 per cent) held a bachelor degree with 9 per cent holding a master's or doctoral degree.

\subsection{Measures}

The authors assessed affective commitment (Cronbach's $\alpha=.94)$ with 6 items from the scale from the salient work of Meyer and Allen (1991) in which they proposed a threefactor model for measuring organisational commitment. Specifically, the authors chose the subscale for affective commitment along with previous empirical studies. As a frequently used scale for assessing affective commitment, its content validity is guaranteed. A sample item includes 'I would be happy to spend the rest of my career in this organisation'. The authors scored all items from 1 (strongly disagree) to 6 (strongly agree). High scores reflect high levels of affective commitment. The composite reliability (CR) and average variance extracted (AVE) for this construct were .93 and .68, respectively.

The authors assessed OPO (Cronbach's $\alpha=.87$ ) with 6 items from the Psychological Ownership Scale (Van Dyne and Pierce, 2004). As the original psychological ownership scale was developed to assess the sense of personal control whereas the organisation is a collective concept, the authors changed the wordings of the original items to suit the context of this research. A sample item includes 'The 
performance of this company is largely dependent on my effort'. The authors scored all items from 1 (strongly disagree) to 6 (strongly agree). High scores reflect high levels of OPO. The CR and AVE for this construct were .85 and .55 , respectively.

The authors assessed KPO (Cronbach's $\alpha=.81$ ) by adapting the scale proposed by Avey's et al. (2009) revised defensive psychological ownership scale. Following the logic of psychological ownership (Pierce et al., 2001), KPO is similar to the original definition of psychological ownership in many aspects. The authors define KPO as the psychological sense or status toward controlling personal knowledge, and take the knowledge as a possession of personal belonging'. Along with prior literature, the authors developed and refined the scale of KPO and finally obtained four items. A sample item includes 'I feel it is necessary to protect self-knowledge to prevent others from stealing it'. The authors scored all items from 1 (strongly disagree) to 6 (strongly agree). High scores reflect high level of KPO. The CR and AVE for this construct were .82 and .62 , respectively.

The authors assessed common knowledge sharing (Cronbach's $\alpha=.90$ ) and key knowledge sharing (Cronbach's $\alpha=.86$ ) using the eight items adapted from Van den Hooff and De Ridder (2004) who distinguished between knowledge donating and knowledge collecting as parts of knowledge sharing; the authors focused on knowledge donating in this study. Generally, common knowledge sharing and key knowledge sharing are two dimensions of knowledge sharing, each of them having four items. Based on preceding arguments and also the validity test in the following section, the authors treated common knowledge sharing and key knowledge sharing as two distinct constructs. A sample item of common knowledge sharing includes 'I would like to communicate with colleagues about my common working experience'. The authors scored all items from 1 (strongly disagree) to 6 (strongly agree). High scores reflect high 
level of knowledge sharing. The CR and AVE for this construct were .89 and .67 , respectively. A sample item of key knowledge sharing includes 'I am willing to share with colleagues important working knowledge or skills'. The CR and AVE for this construct were .85 and .58 , respectively.

\subsection{Control variable}

The authors controlled for the effect of gender, tenure, education level and ownership of the company in which the respondent worked. This was because prior studies suggested that female workers are more likely to attach emotion to an organisation (Chiu and $\mathrm{Ng}$, 1999), and the authors predicted that OPO might be affected by an employee's tenure while individuals with a higher level of education would be more likely to protect their personal knowledge. Finally, some scholars indicated that foreign invested companies have a stronger climate for innovation (Cheung and Lin, 2004), so the authors hoped to control for such an effect on knowledge sharing by adding ownership as a control variable into the following analyses.

\section{Analysis and Results}

Table 1 reports the means, standard deviations, correlations and reliability coefficients of variables examined in this research. The reliability coefficients suggest that the internal consistency of all scales reached an acceptable level. The correlation table indicates that affective commitment and OPO were highly correlated $(r=.78)$. These correlations were not inconsistent with previous studies. Although highly correlated $(r=.44)$, common knowledge sharing and key knowledge sharing can receive different effects from antecedents. Rather than combining them as a single knowledge sharing construct, which may produce potentially biased results, the authors examined them separately. Moreover, the high correlation suggests a positive association between these two types of knowledge sharing providing support for the prediction in hypothesis $6 \mathrm{a}$. 
INSERT TABLE 1 ABOUT HERE

\subsection{Confirmatory factor analyses and measurement model}

Before testing the hypothesised model, the authors confirmed that the measurement model had acceptable fit with the data. A preliminary CFA suggested that all items loaded reasonably well on their latent factors. Along with prior studies, the authors parcelled items for each subscale in a pair-wise manner and examined whether these parcelled variables loaded adequately onto each latent variable. Following this, the authors ran a CFA for a measurement model with parcelled variables. Figure 1 indicates that the measurement model provided a good fit for the data $\left(\chi^{2}(44,293)=65.40\right.$, $p<0.02, \mathrm{CFI}=.99, \mathrm{TLI}=.98, \mathrm{RMSEA}=.04, \mathrm{SRMR}=.03)$.

\section{INSERT FIGURE 1 ABOUT HERE}

The authors then compared the measurement model with several other competing measurement models to test for discriminant validity among our variables. In competing measurement model 1 , the authors assumed affective commitment was an indicator of OPO. In competing measurement model 2, the authors assumed OPO and KPO were indicators of overall psychological ownership. In competing measurement model 3, the authors assumed common knowledge sharing and key knowledge sharing to be indicators of knowledge sharing.

INSERT TABLE 2 ABOUT HERE

Table 2 documents the outcomes of the chi-square comparison tests. The right 
column of Table 2 shows that the differences in chi-square between competing measurement models and the hypothesised measurement model were significant. In other words, the hypothesised model provided a better fit for the data than other alternative models. This indicates that the variables in this research were empirically distinct from others and common knowledge sharing and key knowledge sharing were best analysed as separate constructs.

\subsection{Common method variances tests}

As the data were obtained mainly from the same respondents and all five constructs used subjective measures, a possibility of common method bias exists. Along with prior studies, the authors tested this bias using the Harman one-factor test (Scott and Bruce, 1994; Konrad and Linnehan, 1995; Simonin, 2004). Specifically, an exploratory factor analysis (EFA) using all the items was conducted. The result showed that five factors accounted for 66.65 per cent of the variance with the first factor explaining 29.19 per cent of the total variance. This result indicated that the common method bias was not a significant issue in the study (Podsakoff and Organ, 1986).

\subsection{Model testing}

The authors adopted structural equation modelling with Mplus 6.12 (Muthén and Muthén, Los Aageles, CA, USA; www.statmodel.com) to test the hypothesised structural model. Figure 2 below illustrates the results of the hypothesised structural model with item parcels.

INSERT FIGURE 2 ABOUT HERE

The hypothesised model provided a reasonably good fit with the data after controlling for the effects of gender, tenure and education level and ownership of company $\left(\chi^{2}(79,293)=145.17, p<.01, \quad\right.$ CFI $=0.97, \quad$ TLI $=0.96, \quad$ RMSEA $=0.05$, 
$\mathrm{SRMR}=0.05)$. The authors then conducted the nested model analysis suggested by Anderson and Gerbing (1988) to assess the absolute fit of the hypothesised model. Specifically, the hypothesised model was compared with a less constrained model where paths were added from affective commitment to common knowledge sharing and key knowledge sharing. The less constrained model is depicted in Figure 3.

\section{INSERT FIGURE 3 ABOUT HERE}

The chi-square difference between the hypothesised model $\left(\chi^{2}(79,293)=145.17\right.$, $p<.01)$ and less constrained model $\left(\chi^{2}(77,293)=141.17, p<.01\right)$ was non-significant $\left(\Delta \chi^{2}=4.08, p<.13, \Delta d f=2\right)$. Therefore, the hypothesised model was a better fit for the data than the less constrained model.

The analysis results indicated that affective commitment was positively and significantly associated with OPO $(\beta=.86, p<.01)$ whereas affective commitment was positively and insignificantly related with $\mathrm{KPO}(\beta=.12, p=.10)$. Thus Hypothesis 1 was supported but Hypothesis 2 was not supported. Consistent with the hypotheses, OPO was positively and significantly associated with both common knowledge sharing $(\beta=.49, p<.01)$ and key knowledge sharing $(\beta=.16, p<.05)$ after controlling for the effects of KPO. Meanwhile, after controlling for the effects of OPO, KPO was negatively and significantly related to both common knowledge sharing ( $\beta=-.13$, $p<.05)$ and key knowledge sharing $(\beta=.19, p<.01)$. Thus, Hypotheses 3,4 and $6 a$ were supported.

In order to test Hypotheses $5 \mathrm{a}, 5 \mathrm{~b}, 6 \mathrm{~b}$ and $6 \mathrm{c}$, the authors examined the significance of multiple mediators. Preacher and Hayes (2008) suggested examining the specific 
indirect effect related to each mediator as well as the total indirect effect associated with all of them. Specifically, following their suggestion, the authors adopted the biascorrected (BC) bootstrapping confidence interval (CI) analyses with a 5000 bootstrap sample in Mplus to investigate whether the two types of psychological ownership and common knowledge sharing played significant mediating roles in corresponding relationships proposed in Hypotheses 5a, 5b, 6b and 6c.

Compared with the traditional method that tests mediation effect (Baron and Kenny, 1986), the BC bootstrapping CI analyses have several advantages when testing for multi-mediation. First, by controlling for other potential indirect effects, this method can guarantee the test results are specific to each specific mediator. Second, prior studies pointed out that the traditional method is largely dependent on testing each indirect effect separately via many simple mediators while this method may yield biased parameter estimates which can be avoided by using a multi-mediator (Preacher and Hayes, 2008). Third, it is common to find that the assumption of a normal sampling distribution is problematic using survey data, and this method provides a robust test of hypotheses even when this assumption is mildly violated (MacKinnon, Lockwood, and Williams, 2004; Preacher and Hayes, 2008).

Along with previous studies, the authors set 95 per cent CIs for BC bootstrapping CI analyses, adjusting for median biasness and skewness. Preacher and Hayes (2008) suggested that if a mediator mediates the relationship between the independent and dependent variables significantly, the range of the 95 percent $\mathrm{BC}$ bootstrapping $\mathrm{CI}$ of its indirect effect will not contain 0 . Based on this criterion, the authors examined the estimated results in Table 3.

INSERT TABLE 3 ABOUT HERE 
First, the sum of indirect effects from affective commitment to common knowledge sharing was 0.40 (95 per cent $\mathrm{BC}$ bootstrapping $\mathrm{CI}=0.27,0.53)$. The specific indirect effect from affective commitment to common knowledge sharing via OPO was 0.42 $(\mathrm{CI}=0.29,0.54)$, and the estimated specific indirect effect from via knowledge psychological ownership was $-0.02(\mathrm{CI}=-0.04,0.01)$. These results indicated that OPO significantly mediated the relationship between affective commitment and common knowledge sharing whereas knowledge psychological ownership did not.

Second, the sum of indirect effects from affective commitment to key knowledge sharing was $0.29(\mathrm{CI}=0.16,0.42)$. The specific indirect effect from affective commitment to key knowledge sharing via OPO was $0.14(\mathrm{CI}=0.01,0.27)$, and the estimated specific indirect effect from via knowledge psychological ownership was $0.02(\mathrm{CI}=-0.05,0.01)$. These results indicated that $\mathrm{OPO}$ significantly mediated the relationship between affective commitment and key knowledge sharing whereas knowledge psychological ownership did not. Hence, Hypothesis 5a was supported whereas Hypothesis $5 \mathrm{~b}$ was not.

Analyses also showed that the specific indirect effect from OPO to key knowledge sharing was $0.21(\mathrm{CI}=0.11,0.31)$. And the specific indirect effect from KPO to key knowledge sharing was $-0.06(\mathrm{CI}=-0.11,-0.01)$. These results suggested that common knowledge sharing significantly mediated the relationships between the two types of psychological ownership and key knowledge sharing. Thus, Hypothesis $6 \mathrm{~b}$ was supported.

Finally, the specific indirect effect from affective commitment to key knowledge sharing via OPO and then via common knowledge sharing was $0.18(\mathrm{CI}=0.09,0.27)$, and the specific indirect effect from via KPO and then via common knowledge sharing was $-0.01(\mathrm{CI}=-0.02,0.01)$. These results indicated that $\mathrm{OPO}$ and common knowledge 
sharing significantly mediated the relationship between affective commitment and key knowledge sharing whereas KPO and common knowledge sharing did not. Hence, Hypothesis 6c was partially supported.

\subsection{Alternative models testing}

Since alternative relationships between variables in the hypothesised model, e.g., OPO predicts affective commitment, exist in prior studies, the authors tested the robustness of the model by performing a series of comparisons between the hypothesised model with four alternative models with alternate explanations of the relationships between variables in this study. In alternative model 1, the authors hypothesised OPO predicted affective commitment and KPO. In turn, affective commitment and KPO predicted common knowledge sharing and key knowledge sharing. In alternative model 2 , the authors hypothesised affective commitment predicted common knowledge sharing and key knowledge sharing. Common and key knowledge sharing subsequently predicted organisation and KPO. In alternative model 3, the authors hypothesised common and key knowledge sharing to predict OPO and KPO. OPO and KPO, in turn, predicted affective commitment. In alternative 4, the authors hypothesised common and key knowledge sharing predicted affective commitment. Affective commitment subsequently predicted OPO and KPO.

INSERT TABLE 4 ABOUT HERE

Since the hypothesised model and alternative models were not nested, the authors compared the Akaike information criterion (AIC) and Bayesian information criterion (BIC) to assess the quality of the models. Chen and Lim (2012) suggested that the smaller of the two indicators, the more parsimonious and better fit of the model. As 
reported in Table 4, except the BIC of the hypothesised model (8644.43) being a little bigger than alternative model 1 (88624.26), the AIC and BIC indices of the hypothesised model were the smallest among all the models. Combined with other fitness indices, the hypothesised model exhibited the best fit for the data compared to alternative models.

\section{Discussion}

In this study, the authors connected affective commitment with knowledge sharing. More specifically, the authors introduced two types of psychological ownership, i.e. OPO and KPO, as mediators for the relationships between affective commitment and both common knowledge sharing and key knowledge sharing. Consistent with the authors' arguments, affective commitment was positively related to OPO, which was in line with prior studies (Van Dyne and Pierce 2004). The results support the notion that affective commitment is an antecedent variable of $\mathrm{OPO}$, which extends the existing literature on affective commitment and psychological ownership (Brooks and Wallace, 2006). The prediction that OPO mediates the relationship between affective commitment and both common and key knowledge sharing was also supported. This result indicated that affective commitment stimulates employees' altruistic spirit through their psychological ownership of the organisation and then affects knowledge sharing. It also extends prior studies that place affective commitment as a direct antecedent variable of knowledge sharing. More importantly, the authors conducted a nested model analysis in which the authors tested the direct effect of affective commitment on knowledge sharing after controlling for the mediating effect of psychological ownership. The results suggest that none of these direct effects were significant. Hence, the authors argue that the relationship between affective commitment and knowledge sharing is much more complicated than understood in previous studies, and that OPO is a critical mediator that 
transfers the positivity of affective commitment to knowledge sharing.

In addition, the authors found employees who care more about controlling their personal knowledge (KPO) were less likely to share knowledge with others than those who care less. Interestingly, KPO had a stronger negative effect on key knowledge sharing than on common knowledge sharing, whereas OPO had a stronger positive effect on common knowledge sharing than on key knowledge sharing. These results indicate that it is more difficult to share key knowledge than to share common knowledge.

The empirical tests also supported the prediction that common knowledge sharing is positively related to key knowledge sharing. Rather than simply distinguishing knowledge sharing as donating and collecting knowledge, the authors proposed that a very important concern about whether or not to share knowledge with others was largely dependent on the nature of the knowledge. The findings suggest that common knowledge sharing can encourage employees to share their key knowledge with others. A potential explanation for this positive association is that knowledge senders may form a stable cognition by sharing with others. In other words, the more common knowledge sharing is, the more likely it is that individuals will believe sharing key knowledge with colleagues will not adversely affect their core interests. Thus, a climate that encourages employees to share ideas, experiences, skills, or even daily life stories will eventually promote key knowledge sharing.

Additionally, common knowledge sharing played a mediating role in both the relationship between psychological ownership and key knowledge sharing and the relationship between affective commitment and key knowledge sharing. This result indicates that knowledge sharing itself is complex and contains at least two levels. Compared with the extant studies that perceive knowledge sharing as a simple extra-role 
behaviour, this study extends the knowledge sharing literature by emphasising the two dimensions of knowledge sharing and suggesting possible roles of common knowledge sharing in mediating the relationship between other psychological perceptions and key knowledge sharing.

\section{Conclusion}

\subsection{Brief summary of the paper's findings}

The current research empirically examines the relationships between affective commitment, psychological ownership and knowledge sharing. Specifically, the authors argue that both organisation-based (OPO) and knowledge-based (KPO) psychological ownership mediate the relationship between affective commitment and knowledge sharing. The empirical analysis based on structural equation modelling (SEM) with a sample of 293 employees supported the conceptual model: affective commitment has a significant positive effect on OPO but no effect on KPO, OPO is positively related to both common and key knowledge sharing while KPO exerts a negative impact on both, common knowledge sharing is positively related to key knowledge sharing, and the relationship between affective commitment and key knowledge sharing is multimediated by OPO and common knowledge sharing.

\subsection{Limitations of the research and findings}

This paper has several limitations that future research might be able to overcome. First of all, the valid respondents in the sample were relatively young. This might affect the result since younger workers may have strong intentions to share knowledge but they actually have insufficient knowledge accumulation. Though the authors took this concern into account by controlling for both age and tenure of respondents in 
estimations, future research should aim to collect a sample with a more balanced age structure and examine the effect of these factors on both common and key knowledge sharing. Second, the authors recognise that this research was carried out in the Chinese national context, which may not provide a suitable basis for generalising the findings. However, having considered companies of various size in different industries and locations in China, this gives greater validity to this research regarding the generalisation of the findings. Thirdly, the authors realise that the self-reported and cross-sectional nature of the data impedes us from exploring causal relationships between variables. To obtain better inferences on how affective commitment and psychological ownership influence common and key knowledge sharing, a multi-wave or longitudinal survey is needed. Such an approach will help us to better understand how affective commitment and psychological ownership impact knowledge sharing over time.

\subsection{Implications for practitioners and researchers}

Findings of this research provide a detailed micro-foundation that links individual cognition and behaviour. They are also useful for researchers and practitioners, especially HR managers. First of all, human resource management (HRM) practices that improve employees' feeling as the owner of the company will encourage employees to share common knowledge with colleagues and team members. However, more attention should be given to how HR managers can design appropriate incentives to encourage employees to share their core-interest related knowledge (Whicker and Andrews, 2004). This means that apart from improving employees' emotional attachments to organisations such as setting comprehensive salary systems that encourage staff welfare and performance, HR managers should design rules and programmes to encourage employees' participation in decision making. Similarly, an intention of protecting 
personal intellectual capital will be more likely to prevent employees from sharing key knowledge compared to sharing common knowledge. Therefore, how to overcome the 'psychological territoriality' of knowledge is directly associated with accumulating valuable knowledge within an organisation.

Secondly, as there is a negative effect of KPO on knowledge sharing, HR departments are encouraged to help employees design a long-term career development path, which should be in line with an organisation's future development objective. This approach aims at mitigating the mental defence and prevention of sharing their knowledge with other colleagues or team members. Thirdly, the positive relationship between common knowledge sharing and key knowledge sharing suggests HR managers and supervisors in each department should produce an innovative climate that can facilitate daily communication about any work-related issue. Such a climate is helpful to aid employees in sharing core knowledge within the organisational boundary. Some proper programmes, e.g., flexible organisational design, that encourage employees to collaborate with others in the organisation should be considered by HR departments, which assists employees in engaging in knowledge sharing that enhances organisational performance (Han et al., 2010).

Finally, contrary to the hypotheses, affective commitment was positively but insignificantly related to KPO, and the mediating effect of KPO was also not significant. These results were unexpected as prior studies suggested that individuals with a high level of affective commitment are more willing to work for an organisation, but no concrete empirical evidence indicates a link between personal emotional attachment to an organisation and personal control of knowledge. In other words, individuals' emotional investment in an organisation is not strong enough to mitigate the prevention aspect of psychological ownership of knowledge. One plausible reason is that employees 
today are more likely concerned about their personal knowledge since it is an essential source for finding jobs and promoting careers. Furthermore, the climate and culture of Chinese companies are not the same as those in Western countries (Gamble and Tian, 2012). Chinese employees may have a clear distinction between personal and organisational boundaries (Ralston, Holt, Terpstra, and Kai-Cheng, 1997; Stanat, 2006), whereas workers in Western companies usually have higher awareness of intellectual property rights and thus they are more likely to protect their personal knowledge Therefore, HR managers in different contexts are encouraged to propose specific methods to facilitate employees' key knowledge sharing.

\subsection{Possible areas for future research}

Indeed, findings of this paper suggest a number of directions and opportunities for future studies to explore the areas of knowledge management and organisational behaviour. Among the many potential research questions, the authors suggest three most interesting and promising possibilities. First and foremost, the authors recommend future studies explore antecedents that affect psychological territoriality, e.g., KPO, and whether there are variables that moderate the relationships between OPO and KPO and knowledge sharing. Moreover, future studies could examine factors that may mediate the relationship between common knowledge sharing and key knowledge sharing, and the authors believe the mediating role of trust between knowledge sender and receiver is worthy to investigate. Finally, the current study mainly focused on the knowledge sharing at an individual level, therefore the authors suggest future studies re-examine the hypotheses proposed in this research at the team level. This research would be both theoretically intriguing and practically important. 
Acknowledgements - The corresponding author is Dr Jian Li, Business School of

Hunan University, email: lijian_phd@126.com. The authors wish to thank Professor Rory

Chase, the Editor in Chief of $J K M$, and the anonymous referees for their constructive comments and suggestions.

\section{References}

Allen, N. J., \& Meyer, J. P. (1990). The measurement and antecedents of affective, continuance and normative commitment to the organization. Journal of occupational psvchologv, 63(1), 1-18.

Anderson, J. C., \& Gerbing, D. W. (1988). Structural equation modeling in practice: A review and recommended two-step approach. Psvchological bulletin, 103(3), 411.

Argote, L., \& Ingram, P. (2000). Knowledge transfer: A basis for competitive advantage in firms. Organizational behavior and human decision processes, 82(1), 150-169.

Argote, L., McEvily, B., \& Reagans, R. (2003). Managing knowledge in organizations: An integrative framework and review of emerging themes. Management science. 49(4). 571-582.

Augier, M., Shariq, S. Z., \& Vendelø, M. T. (2001). Understanding context: its emergence, transformation and role in tacit knowledge sharing. Journal of Knowledge Management, 5(2), 125-137.

Avey, J. B., Avolio, B. J., Crossley, C. D., \& Luthans, F. (2009). Psychological ownership: Theoretical extensions, measurement and relation to work outcomes. Journal of Organizational Behavior, 30(2), $173-191$.

Baron, R. M., \& Kenny, D. A. (1986). The moderator--mediator variable distinction in social psychological research: Conceptual, strategic, and statistical considerations. Journal of personalitv and social psvchologv, 51(6), 1173.

Baumard, P. (1999). Tacit knowledge in organizations. Sage.

Becker, T. E., \& Kernan, M. C. (2003). Matching commitment to supervisors and organizations to in-role and extra-role performance. Human Performance, 16(4), 327-348.

Belk, R. (1988). Possessions and Self. Wiley Online Library.

Bock, G.-W., Zmud, R. W., Kim, Y.-G., \& Lee, J.-N. (2005). Behavioral intention formation in knowledge sharing: Examining the roles of extrinsic motivators, social-psychological forces, and organizational climate. MIS quarterly, 87-111.

Bowen, D. E., \& Lawler, E. E. (1992). Total quality-oriented human resources management. Organizational Dvnamics, 20(4), 29-41.

Brislin, R. W. (1970). Back-translation for cross-cultural research. Journal of cross-cultural psvchologv, l(3), 185-216.

Brooks, G. R., \& Wallace, J. P. (2006). A discursive examination of the nature, determinants and impact of organisational commitment. Asia Pacific Journal of Human Resources, 44(2), 222-239.

Brown, G., Lawrence, T. B., \& Robinson, S. L. (2005). Territoriality in organizations. Academv of Management Review, 30(3), 577-594.

Cabrera, E. F., \& Cabrera, A. (2005). Fostering knowledge sharing through people management practices. The International Journal of Human Resource Management, 16(5), 720-735.

Camelo-Ordaz, C., Garcia-Cruz, J., Sousa-Ginel, E., \& Valle-Cabrera, R. (2011). The influence of human resource management on knowledge sharing and innovation in Spain: the mediating role of affective commitment. The International Journal of Human Resource Management, 22(07), 1442-1463.

Carmeli, A. (2005). Perceived external prestige, affective commitment, and citizenship behaviors. Organization Studies, 26(3), 443-464.

Chen, D. J. Q., \& Lim, V. K. G. (2012). Strength in adversity: The influence of psychological capital on job search. Journal of Organizational Behavior, 33(6), 811-839.

Cheung, K., \& Lin, P. (2004). Spillover effects of FDI on innovation in China: Evidence from the provincial data. China Economic Review, 15(1), 25-44. 
Chiu, W. C. K., \& Ng, C. W. (1999). Women-friendly HRM and organizational commitment: A study among women and men of organizations in Hong Kong. Journal of Occupational and Organizational Psvchology, 72(4), 485-502.

Cohen, W. M., \& Levinthal, D. A. (1990). Absorptive capacity: a new perspective on learning and innovation. Administrative science quarterlv. 128-152.

Cram, F., \& Paton, H. (1993). Personal possessions and self-identity: The experiences of elderly women in three residential settings. Australasian Journal on Ageing, 12(1), 19-24.

Cummings, J. N. (2004). Work groups, structural diversity, and knowledge sharing in a global organization. Management science, 50(3), 352-364.

Cushen, J., Thompson, P., 2012. Doing the right thing? HRM and the angry knowledge worker. New Technologv. Work and Emplovment 27, 79-92.

Davenport, T. H., David, W., \& Beers, M. C. (1998). Successful knowledge management projects. Sloan management review, 39(2), 43-57.

Devinney, T. (2013). IS MICROFOUNDATIONAL THINKING CRITICAL TO MANAGEMENT THOUGHT AND PRACTICE? The Academv of Management Perspectives.27(2), 81-84.

Dittmar, H. (1992). Perceived material wealth and first impressions. British Journal of Social Psvchologv, 31(4), 379-391.

Ellemers, N., Kortekaas, P., \& Ouwerkerk, J. W. (1999). Self-categorisation, commitment to the group and group self-esteem as related but distinct aspects of social identity. European journal of social psychology, 29(2-3), 371-389.

Felin, T., \& Barney, J. B. (2013). Microfoundations of organization and strategy: Half-truths, truths and future Directions. Academy of Management Perspectives, 27(2). 72-76.

Gagné, M. (2009). A model of knowledge-sharing motivation. Human Resource Management, 48(4), $571-589$.

Gamble, J., \& Tian, A. W. (2012). Intra-national variation in organizational commitment: evidence from the Chinese context. The International Journal of Human Resource Management, (ahead-of-print), $1-23$.

Granovetter, M. S. (1973). The strength of weak ties. American iournal of sociologv. 1360-1380.

Grant, R. M. (1996). Prospering in dynamically-competitive environments: organizational capability as knowledge integration. Organization science, 7(4), 375-387.

Haas, M. R., \& Hansen, M. T. (2007). Different knowledge, different benefits: toward a productivity perspective on knowledge sharing in organizations. Strategic Management Journal, 28(11), 11331153.

Han, T.-S., Chiang, H.-H., \& Chang, A. (2010). Employee participation in decision making, psychological ownership and knowledge sharing: Mediating role of organizational commitment in taiwanese hightech organizations. The International Journal of Human Resource Management, 21(12), 2218-2233.

Hansen, B. E. (1999). Threshold effects in non-dynamic panels: Estimation, testing, and inference. Journal of econometrics, 93(2), 345-368.

Higgins, E. T. (1997). Beyond pleasure and pain. American psvchologist, 52(12), 1280.

Higgins, E. T. (1998). Promotion and prevention: Regulatory focus as a motivational principle. Advances in experimental social psvchologv, 30, 1-46.

Hislop, D. (2003). Linking human resource management and knowledge management via commitment: a review and research agenda. Emplovee relations, 25(2), 182-202.

Hu, L., \& Randel, A. E. (2014). Knowledge Sharing in Teams: Social Capital, Extrinsic Incentives, and Team Innovation. Group \& Organization Management, doi: 10.1177/1059601114520969.

Ibragimova, B. (2006). Propensity for knowledge sharing: An organizational justice perspective. University of North Texas.

Ikujiro, N., \& Hirotaka, T. (1995). The Knowledge Creating Company: how Japanese Companies Ctrate the Dynamics of Innovation. Oxford University Press.

Kark, R., \& Van Dijk, D. (2007). Motivation to lead, motivation to follow: The role of the self-regulatory focus in leadership processes. Academv of Management Review, 32(2), 500-528.

Kim, S., \& Lee, H. (2006). The Impact of Organizational Context and Information Technology on Employee Knowledge-Sharing Capabilities. Public Administration Review, 66(3), 370-385.

Kimberly, J. R., \& Evanisko, M. J. (1981). Organizational innovation: The influence of individual, organizational, and contextual factors on hospital adoption of technological and administrative innovations. Academy of management journal, 24(4), 689-713.

Konrad, A. M., \& Linnehan, F. (1995). Formalized HRM structures: Coordinating equal employment opportunity or concealing organizational practices? Academv of Management Journal, 38(3), 787 820. 
Krogh, G. von, Roos, J., \& Slocum, K. (1994). An essay on corporate epistemology. Strategic Management Journal, 15(S2), 53-71.

Liao, L.-F. (2008). Knowledge-sharing in R\&D departments: a social power and social exchange theory perspective. The International Journal of Human Resource Management, 19(10), 1881-1895.

Liberman, N., Idson, L. C., Camacho, C. J., \& Higgins, E. T. (1999). Promotion and prevention choices between stability and change. Journal of personality and social psvchologv, 77(6), 1135-1145.

Lin, C.-P. (2007). To share or not to share: Modeling tacit knowledge sharing, its mediators and antecedents. Journal of Business Ethics, 70(4), 411-428.

Lin, H.-F. (2007). Effects of extrinsic and intrinsic motivation on employee knowledge sharing intentions. Journal of information science, 33(2), 135-149.

Liu, N.-C., \& Liu, M.-S. (2011). Human resource practices and individual knowledge-sharing behavior an empirical study for Taiwanese R\&D professionals. The International Journal of Human Resource Management, 22(4), 981-997.

Liu, Y., \& DeFrank, R. S. (2012). Self-interest and knowledge-sharing intentions: the impacts of transformational leadership climate and HR practices. The International Journal of Human Resource Management, 24(6), 1151-1164.

Luthans, F. (2002). The need for and meaning of positive organizational behavior. Journal of Organizational Behavior, 23(6), 695-706.

MacKinnon, D. P., Lockwood, C. M., \& Williams, J. (2004). Confidence limits for the indirect effect: Distribution of the product and resampling methods. Multivariate behavioral research, 39(1), 99_ $\underline{128}$.

Masterson, S. S., \& Stamper, C. L. (2003). Perceived organizational membership: An aggregate framework representing the employee--organization relationship. Journal of Organizational Behavior, 24(5), 473-490.

Matzler, K., Renzl, B., Mooradian, T., von Krogh, G., \& Mueller, J. (2011). Personality traits, affective commitment, documentation of knowledge, and knowledge sharing. The International Journal of Human Resource Management, 22(02), 296-310.

Matzler, K., Renzl, B., Müller, J., Herting, S., \& Mooradian, T. A. (2008). Personality traits and knowledge sharing. Journal of Economic Psvchologv, 29(3), 301-313.

McAdam, R., McCreedy, S., (2000). A critique of knowledge management: using a social constructionist model. New Technologv. Work and Emplovment 15, 155-168

McMillan, D. W., \& Chavis, D. M. (1986). Sense of community: A definition and theory. Journal of community psvchologv, 14(1), 6-23.

Meso, P., \& Smith, R. (2000). A resource-based view of organizational knowledge management systems. Journal of Knowledge Management, 4(3), 224-234.

Meyer, J. P., \& Allen, N. J. (1991). A three-component conceptualization of organizational commitment. Human resource management review. 1(1), 61-89.

Meyer, J. P., Stanley, D. J., Herscovitch, L., \& Topolnytsky, L. (2002). Affective, continuance, and normative commitment to the organization: A meta-analysis of antecedents, correlates, and consequences. Journal of vocational behavior, 61(1), 20-52.

Nahapiet, J., \& Ghoshal, S. (1998). Social capital, intellectual capital, and the organizational advantage. Academy of management review, 23(2), 242-266.

Nelson, R. R., \& Winter, S. G. (1982). The Schumpeterian tradeoff revisited. The American Economic Review, 72(1), 114-132.

Nonaka, I., \& Takeuchi, H. (1996). The knowledge-creating company: How Japanese companies create the dynamics of innovation. Long Range Planning, 29(4), 592-610.

Nonaka, I., Von Krogh, G., \& Voelpel, S. (2006). Organizational knowledge creation theory: evolutionary paths and future advances. Organization studies, 27(8), 1179-1208.

O'driscoll, M. P., Pierce, J. L., \& Coghlan, A.-M. (2006). The Psychology of Ownership Work Environment Structure, Organizational Commitment, And Citizenship Behaviors. Group \& Organization Management, 31(3), 388-416.

Pierce, J. L., Kostova, T., \& Dirks, K. T. (2001). Toward a theory of psychological ownership in organizations. Academv of Management Review, 26(2), 298-310.

Pierce, J. L., Kostova, T., \& Dirks, K. T. (2003). The state of psychological ownership: Integrating and extending a century of research. Review of general psvchologv. 7(1), 84-107.

Pierce, L. (2012). Organizational structure and the limits of knowledge sharing: Incentive conflict and agency in car leasing. Management science, 58(6), 1106-1121.

Podsakoff, P. M., MacKenzie, S. B., Paine, J. B., \& Bachrach, D. G. (2000). Organizational citizenship behaviors: A critical review of the theoretical and empirical literature and suggestions for future research. Journal of management, 26(3), 513-563. 
Podsakoff, P. M., \& Organ, D. W. (1986). Self-reports in organizational research: Problems and prospects. Journal of management, 12(4), 531-544.

Polanyi, M. (1966). The logic of tacit inference. Philosophy, 41(155), 1-18.

Preacher, K. J., \& Hayes, A. F. (2008). Asymptotic and resampling strategies for assessing and comparing indirect effects in multiple mediator models. Behavior research methods, 40(3), 879-891.

Ralston, D. A., Holt, D. H., Terpstra, R. H., \& Kai-Cheng, Y. (1997). The impact of national culture and economic ideology on managerial work values: A study of the United States, Russia, Japan, and China. Journal of International Business Studies, 177-207.

Ramirez, M., Li, X., (2009). Learning and sharing in a Chinese high-technology cluster: a study of interfirm and intra-firm knowledge flows between R\&D employees. New Technologv. Work and Emplovment 24, 277-296.

Reagans, R., \& McEvily, B. (2003). Network structure and knowledge transfer: The effects of cohesion and range. Administrative science quarterlv. 48(2), 240-267.

Schwaer, C., Biemann, T., \& Voelpel, S. (2012). Antecedents of employee's preference for knowledgesharing tools. The International Journal of Human Resource Management, 23(17), 3613-3635.

Scott, S. G., \& Bruce, R. A. (1994). Determinants of innovative behavior: A path model of individual innovation in the workplace. Academy of management journal, 37(3), 580-607.

Sieger, P., Bernhard, F., \& Frey, U. (2011). Affective commitment and job satisfaction among non-family employees: Investigating the roles of justice perceptions and psychological ownership. Journal of Familv Business Strategv, 2(2), 78-89.

Simonin, B. L. (2004). An empirical investigation of the process of knowledge transfer in international strategic alliances. Journal of international business studies, 35(5), 407-427.

Sitlington, H. (2012). Knowledge sharing: implications for downsizing and restructuring outcomes in Australian organisations. Asia Pacific Journal of Human Resources, 50(1), 110-127.

Spender, J. C. (1996). Making knowledge the basis of a dynamic theory of the firm. Strategic management iournal. 17, 45-62.

Stanat, M. (2006). China's Generation Y: Understanding the Future Leaders of the Worlds Next Superpower. New York: Homa \& Sekey Books.

Swift, M. L., \& Virick, M. (2013). Perceived Support, Knowledge Tacitness, and Provider Knowledge Sharing. Group \& Organization Management, 38(6), 717-742.

Szulanski, G. (2000). The process of knowledge transfer: A diachronic analysis of stickiness. Organizational behavior and human decision processes. 82(1), 9-27.

Van den Hooff, B., \& De Ridder, J. A. (2004). Knowledge sharing in context: the influence of organizational commitment, communication climate and CMC use on knowledge sharing. Journal of knowledge management, 8(6), 117-130.

Van Dyne, L., \& Pierce, J. L. (2004). Psychological ownership and feelings of possession: Three field studies predicting employee attitudes and organizational citizenship behavior. Journal of Organizational Behavior, 25(4), 439-459.

Von Krogh, G. (1998). Care in. California management review, 40(3), 133.

Whicker, L. M., \& Andrews, K. M. (2004). HRM in the Knowledge Economy: Realising the Potential. Asia Pacific Journal of Human Resources, 42(2), 156-165.

Williams, L. J., \& Anderson, S. E. (1991). Job satisfaction and organizational commitment as predictors of organizational citizenship and in-role behaviors. Journal of management, 17(3), 601-617.

Wright, P. M., \& Kehoe, R. R. (2008). Human resource practices and organizational commitment: A deeper examination. Asia Pacific Journal of Human Resources, 46(1), 6-20.

Yen, Y.-F., Tseng, J.-F., \& Wang, H.-K. (2014). Exploring the mediating role of trust on the relationship between guanxi and knowledge sharing: a social network perspective. Asia Pacific Journal of Human Resources.52(2), 173-192.

Zander, U., \& Kogut, B. (1995). Knowledge and the speed of the transfer and imitation of organizational capabilities: An empirical test. Organization science, 6(1), 76-92. 


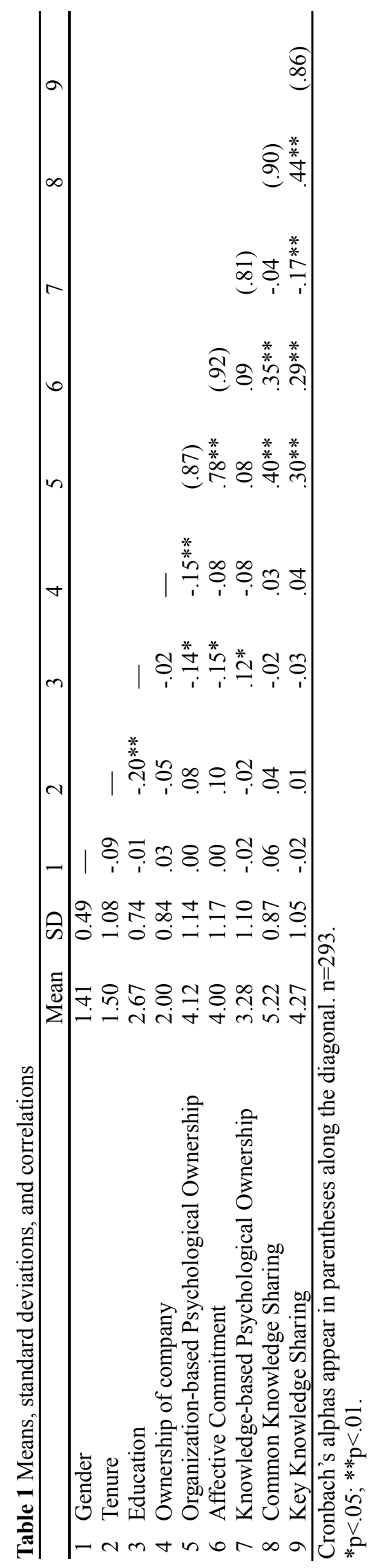


Table 2 Chi-square comparison tests between hypothesized measurement model and alternative measurement models

\begin{tabular}{|c|c|c|c|c|c|c|}
\hline Models & Chi-square & $C F I$ & $T L I$ & RMSEA & SRMR & $\begin{array}{l}\Delta \chi^{2} \text { from hypothesized } \\
\text { measurement model }\end{array}$ \\
\hline Hypothesized measurement model & $\begin{array}{c}\chi^{2}(44,293)=65.40, \\
p<0.02\end{array}$ & 0.99 & 0.98 & 0.04 & 0.03 & - \\
\hline $\begin{array}{l}\text { Alternative measurement model } 1 \\
\text { (affective commitment as an indicator } \\
\text { of organization psychological } \\
\text { ownership) }\end{array}$ & $\begin{array}{c}\chi^{2}(48,293)=172.22 \\
p<.001\end{array}$ & 0.93 & 0.91 & 0.09 & 0.04 & $\begin{array}{l}\Delta \chi^{2}=106.82 \\
p<.001, \Delta d f=4\end{array}$ \\
\hline $\begin{array}{l}\text { Alternative measurement model } 2 \\
\text { (organization and knowledge } \\
\text { psychological ownership as indicators } \\
\text { of an overall psychological ownership) }\end{array}$ & $\begin{array}{c}\chi^{2}(48,293)=343.472 \\
p<.001\end{array}$ & 0.83 & 0.78 & 0.15 & 0.10 & $\begin{array}{l}\Delta \chi^{2}=227.09 \\
p<.001, \Delta d f=4\end{array}$ \\
\hline $\begin{array}{l}\text { Alternative measurement model } 3 \\
\text { (common and key knowledge sharing } \\
\text { as indicators of a knowledge sharing } \\
\text { behavior) }\end{array}$ & $\begin{array}{c}\chi^{2}(48,293)=290.10 \\
p<.001\end{array}$ & 0.87 & 0.82 & 0.13 & 0.07 & $\begin{array}{l}\Delta \chi^{2}=356.22 \\
p<.001, \Delta d f=4\end{array}$ \\
\hline
\end{tabular}


Table 3 Mediation analyses

\begin{tabular}{|c|c|c|c|}
\hline & \multirow[b]{2}{*}{ Estimates } & \multicolumn{2}{|c|}{$\begin{array}{l}\text { Bootsrapping } \\
\text { BC } 95 \% \text { CI }\end{array}$} \\
\hline & & Lower & Upper \\
\hline \multicolumn{4}{|l|}{ Effects of affective commitment to common knowledge sharing } \\
\hline Sum of indirect effect & $.40 * *$ & .27 & .53 \\
\hline \multicolumn{4}{|l|}{ Specific indirect effect } \\
\hline $\begin{array}{l}\text { Affective commitment } \rightarrow \text { organization psychological ownership } \rightarrow \\
\text { common knowledge sharing }\end{array}$ & $.42 * *$ & .29 & .54 \\
\hline $\begin{array}{l}\text { Affective commitment } \rightarrow \text { knowledge psychological ownership } \rightarrow \\
\text { common knowledge sharing }\end{array}$ & -.02 & -.04 & .01 \\
\hline \multicolumn{4}{|l|}{ Effects of affective commitment to key knowledge sharing } \\
\hline Sum of indirect effect & $.29 * *$ & .16 & .42 \\
\hline \multicolumn{4}{|l|}{ Specific indirect effect } \\
\hline $\begin{array}{l}\text { Affective commitment } \rightarrow \text { organization psychological ownership } \rightarrow \text { key } \\
\text { knowledge sharing }\end{array}$ & $.14^{*}$ & .01 & .27 \\
\hline $\begin{array}{l}\text { Affective commitment } \rightarrow \text { knowledge psychological ownership } \rightarrow \text { key } \\
\text { knowledge sharing }\end{array}$ & -.02 & -.05 & .01 \\
\hline $\begin{array}{l}\text { Affective commitment } \rightarrow \text { organization psychological ownership } \rightarrow \\
\text { common knowledge sharing } \rightarrow \text { key knowledge sharing }\end{array}$ & $.18 * *$ & .09 & .27 \\
\hline $\begin{array}{l}\text { Affective commitment } \rightarrow \text { knowledge psychological ownership } \rightarrow \\
\text { common knowledge sharing } \rightarrow \text { key knowledge sharing }\end{array}$ & -.01 & -.02 & .01 \\
\hline \multicolumn{4}{|l|}{$\begin{array}{l}\text { Effects of organization psychological ownership to key knowledge } \\
\text { sharing }\end{array}$} \\
\hline Sum of indirect effect & $.21 * *$ & .11 & .31 \\
\hline \multicolumn{4}{|l|}{ Specific indirect effect } \\
\hline $\begin{array}{l}\text { Organization psychological ownership } \rightarrow \text { common knowledge sharing } \\
\rightarrow \text { key knowledge sharing }\end{array}$ & $.21 * *$ & .11 & .31 \\
\hline \multicolumn{4}{|l|}{ Effects of knowledge psychological ownership to key knowledge sharing } \\
\hline $\begin{array}{l}\text { Sum of indirect effect } \\
\text { Specific indirect effect }\end{array}$ & $-.06^{*}$ & -.11 & -.01 \\
\hline $\begin{array}{l}\text { Knowledge psychological ownership } \rightarrow \text { common knowledge sharing } \rightarrow \\
\text { key knowledge sharing }\end{array}$ & $-.06^{*}$ & -.11 & -.01 \\
\hline
\end{tabular}
$\mathrm{n}=293 . * \mathrm{p}<.05 ; * * \mathrm{p}<.01$. 
Table 4 Comparison of fit indices between hypothesized model and alternative models

\begin{tabular}{cccccccc}
\hline Models & Chi-square & CFI & TLI & RMSEA & SRMR & AIC & BIC \\
\hline Hypothesized model & $\chi^{2}(79,293)=145.17, p<.001$ & 0.97 & 0.96 & 0.05 & 0.04 & 8427.30 & 8644.43 \\
Alternative model 1 & $\chi^{2}(87,293)=169.64, p<.001$ & 0.96 & 0.95 & 0.06 & 0.06 & 8436.58 & 8624.26 \\
Alternative model 2 & $\chi^{2}(78,293)=368.15, p<.001$ & 0.86 & 0.80 & 0.11 & 0.12 & 8655.83 & 8876.64 \\
Alternative model 3 & $\chi^{2}(75,293)=145.10, p<.001$ & 0.97 & 0.95 & 0.06 & 0.04 & 8434.03 & 8665.88 \\
Alternative model 4 & $\chi^{2}(76,293)=165.86, p<.001$ & 0.96 & 0.94 & 0.06 & 0.05 & 8450.90 & 8679.07 \\
\hline
\end{tabular}




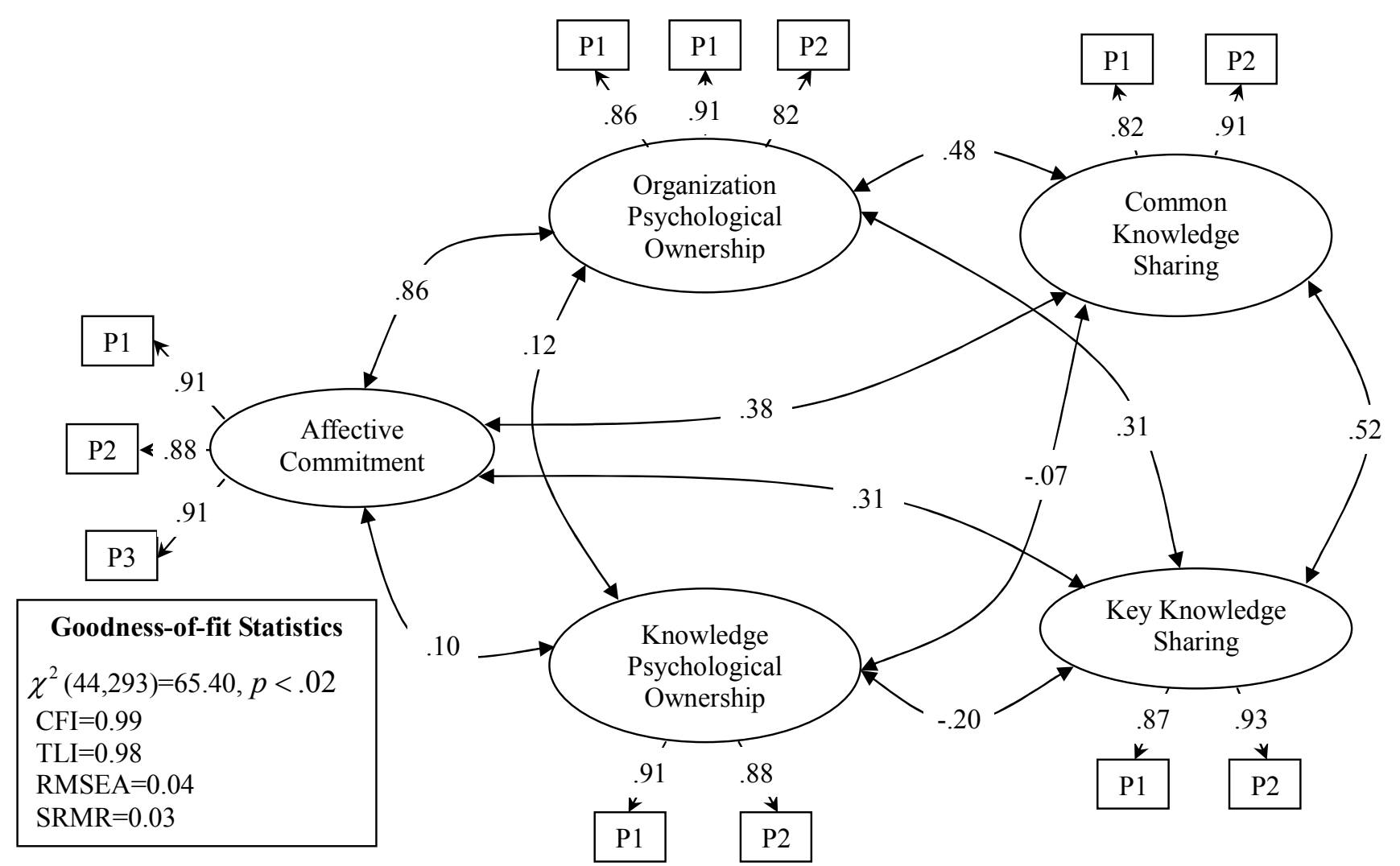

Note: Individual indicators and control variables are omitted due to space constraints, figures from latent variables to $\mathrm{P} 1$ and $\mathrm{P} 2$ are factor loadings of item parcels on latent variables.

Figure 1. Hypothesized measurement model 


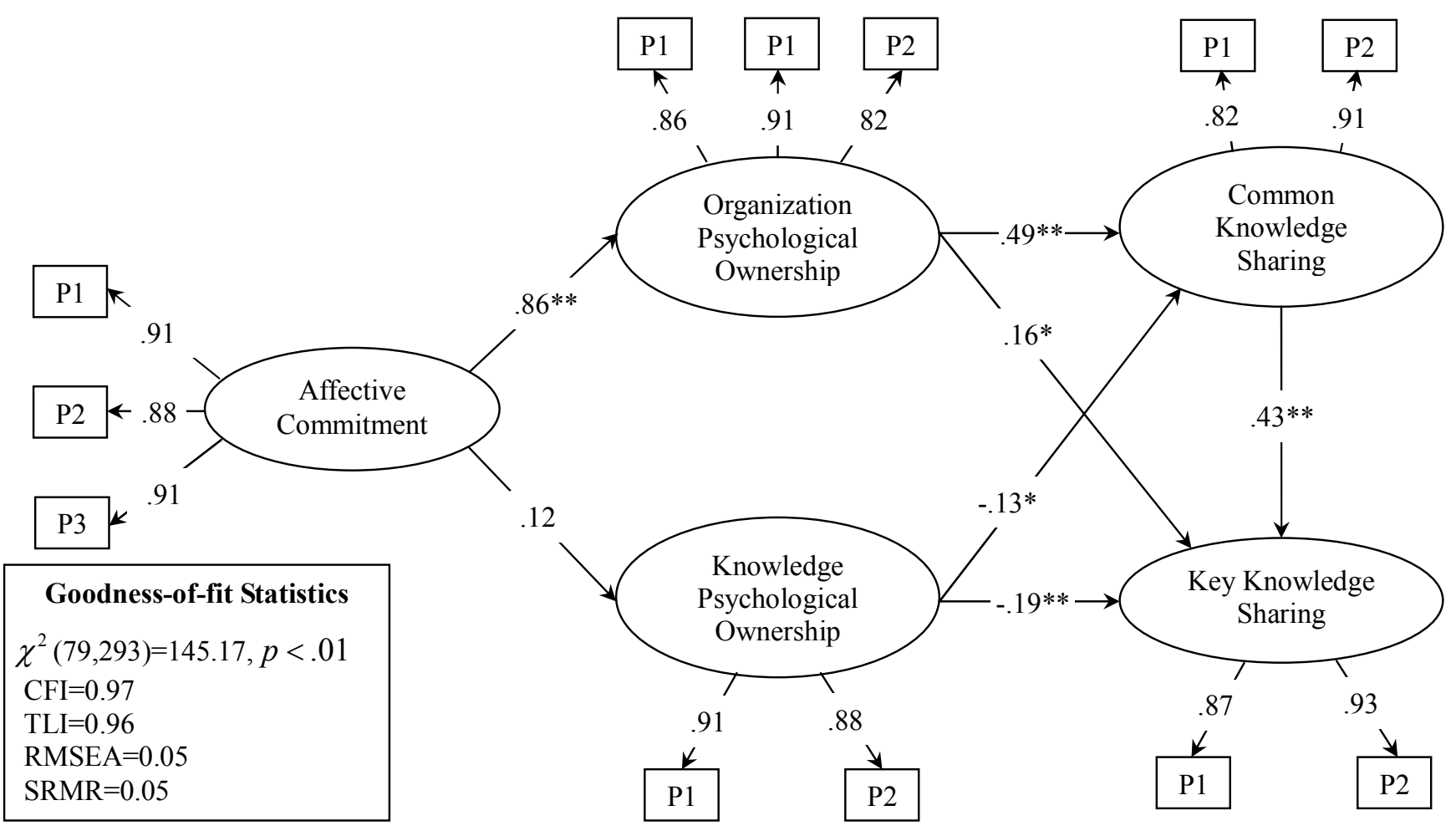

$\mathrm{n}=293, * \mathrm{p}<.05, * * \mathrm{p}<.01$

Note: Individual indicators and control variables are omitted due to space constraints, figures from latent variables to P1 and P2 are factor loadings of item parcels on latent variables.

Figure 2. Structural model after controlling for gender, education, tenure and company ownership 


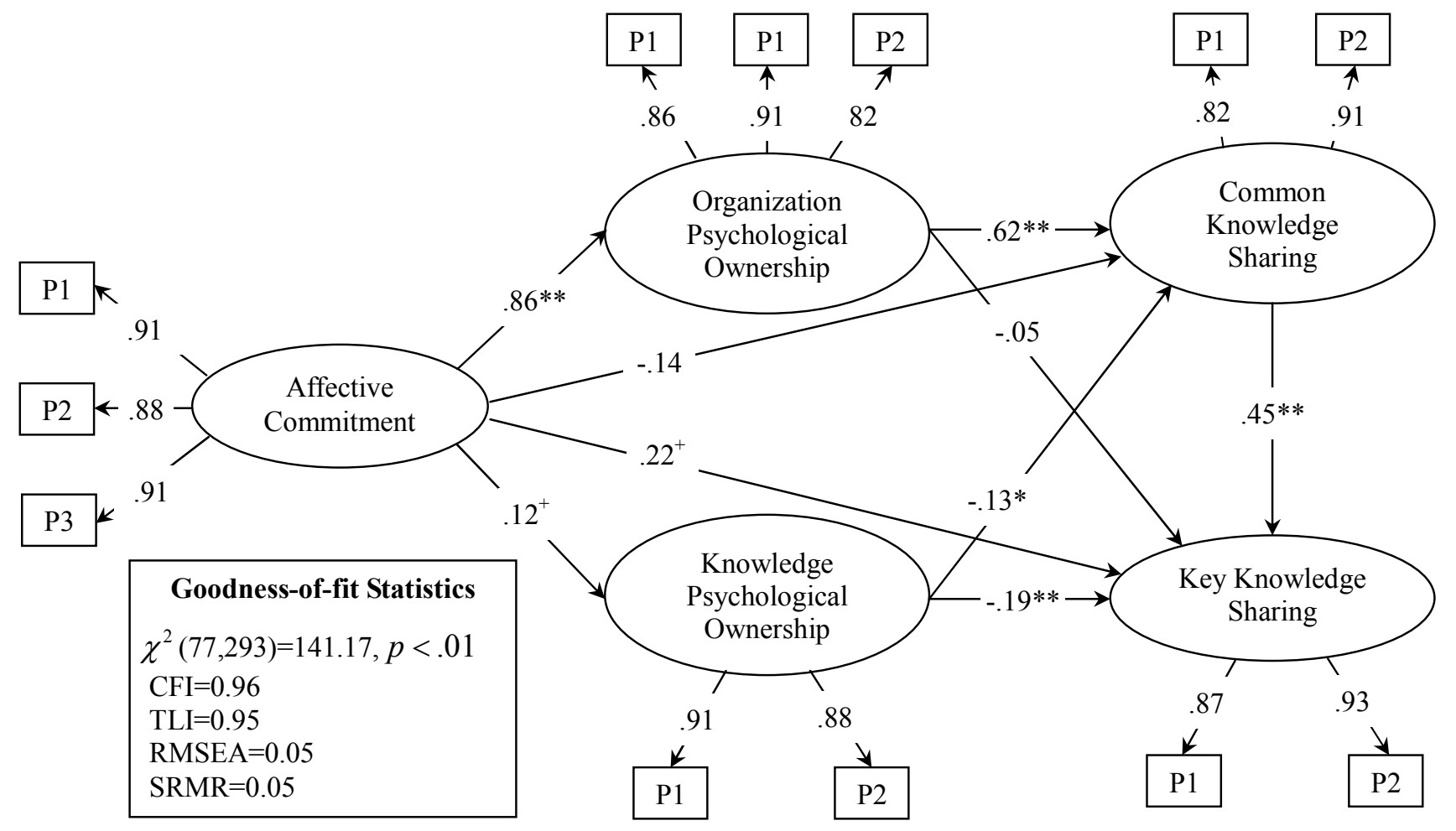

$\mathrm{n}=293,{ }^{*} \mathrm{p}<.05, * * \mathrm{p}<.01,{ }^{+} \mathrm{p}<.10$

Note: Individual indicators and control variables are omitted due to space constraints, figures from latent variables to $\mathrm{P} 1$ and $\mathrm{P} 2$ are factor loadings of item parcels on latent variables.

Figure 3. Structural model with paths added from affective commitment to knowledge sharing

\section{Author biographies}

Dr. Jian Li (PhD, London UK) is an Assistant Professor at the Business School of Hunan University. His research interests focus on technology innovation, R\&D collaborations and industrial relations in China. He has published in Regional Studies, Journal of Technology Transfer, Scientometrics, Technological Analysis \& Strategic Management and Chinese Management Studies. Jian Li is the corresponding author and can be contacted at: lijian_phd@126.com.

Dr. Ling Yuan $(\mathrm{PhD})$ is a Professor in human resource management and labour relations in Business School of Hunan University, China. His research interests focus on 
organizational behaviours of employee in China and labour relations in business sectors. He has published in Chinese Management Studies and over 60 papers in China (CSSCI). Dr Lutao Ning ( $\mathrm{PhD}$, Cambridge UK) is a Senior Lecturer in International Business at the School of Business and Management, Queen Mary, University of London. His research is focused on the area of interntional technology management and innovation and business strategy in an emerging market context. He has previously published in Journals such as Technovation, Scientometrics, International Business Review and Regional Studies.

Dr. Jason Li-Ying (PhD, Hasselt Belgium) is an Associate Professor of Technology and Innovation Management at the Technical University of Denmark. His research interests include open innovation, user-driven innovation, technology transfer, technological capability building by firms in developing countries. His work has been published in journals such as Creativity and Innovation Management, Long Range Planning, Technovation, Journal of Technology Transfer, R\&D Management, Journal of Product Innovation Management, International Journal of Innovation Management, Scientometrics, and Multinational Business Review. 